\title{
Status prawny dzieci nieślubnych na ziemiach polskich w dobie zaborów w świetle Kodeksu Cywilnego Napoleona
}

I. Problemem, który pragnę poruszyć, jest sytuacja dzieci nieślubnych w XIX-wiecznych kodyfikacjach. Jest on według mnie istotny, ponieważ w okresie tym w państwie polskim było wielu młodych ludzi, którzy nie posiadali naturalnych rodziców. Powodów było wiele. Mężczyźni, mężowie, ojcowie wyruszali na powstania, do pracy, ginęli. Żony, matki, zostawały same, nierzadko bez środków do życia. To tylko jedna z licznych hipotez, które prowadziły do sytuacji, że dzieci pozostawały bez prawnych opiekunów.

Zbiorem przepisów prawa cywilnego, który został wprowadzony we Francji w 1804 r. przez Napoleona Bonaparte był „Kodeks Cywilny Napoleona”. Był on pierwszą wielką kodyfikacją prawa francuskiego. Wprowadził wiele nowoczesnych rozwiązań ${ }^{1}$. Umieszczając w nazwie „Kodeks Cywilny Napoleona" swoje imię, dawał wyraz swym szczególnym, osobistym związkom z dziełem. Był on niewątpliwie dumny z pracy. Z perspektywy lat uznał, za najważniejsze osiągnięcie życia. Na wygnaniu na wyspie św. Heleny wygłosił pamiętne słowa: „Waterloo może zatrzeć wspomnienia czterdziestu bitew wygranych, ale jest coś, czego nic nie wymaże, co żyć będzie wiecznie, to jest mój kodeks cywilny" ". Jest to źródło ważne, oddaje ducha epoki, jest zbiorem myśli czołowego XIX-wiecznego polityka.

Kolejnym kodeksem, który jest pozostałością po XIX w. i z którego możemy uzyskać wiedzę o stosunku ojca do dziecka, jest Kodeks Cywilny Królestwa Polskiego (KCKP). Kodeks ten stanowił przeciwstawieństwo Kodeksu Napoleona. W KCKP zawarty został rozszerzony katalog uprawnień dzieci pochodzących ze związków pozamałżeńskich. Zestawiłam te dwa kodeksy ze sobą na zasadzie kontrastu. Oba zawierają wiele interesujących zagadnień. Celem pracy będzie uzyskanie odpowiedzi na szereg pytań dotyczących dzieci nieślubnych. Z uwagi na tematykę zostanie poruszona także kwestia sytuacji

\footnotetext{
${ }^{1}$ K. Sójka-Zielińska, Kodeks Napoleona. Historia i współczesność, Warszawa 2007, s. 53.

${ }^{2}$ Eadem, Wielkie kodyfikacje cywilne XIX wieku, Warszawa 1967, s. 67.
} 
prawnej kobiet, żyjących w XIX-wiecznych realiach na ziemiach polskich. Problem ten warty jest poruszenia, albowiem w świetle unormowań Kodeksu Napoleona dominującą rolę ogrywali głównie mężczyźni.

II. Dzieci nieślubne miały niewątpliwie gorszą pozycję w świetle XIXwiecznych kodyfikacji prawa cywilnego niż te, które pochodziły ze sformalizowanych związków małżeńskich. KCN nie odnosił się w sposób jednolity także do młodych ludzi, pochodzących z nieformalnych związków. Dzieci takie zostały podzielone na dwie, można by dopuścić się o stwierdzenie, pod kategorie. Zgodnie z art. $331 \mathrm{KCN}$,dzieci zrodzone nie w małżeństwie, oprócz zrodzonych w związku kazirodzkim lub cudzołożnym, mogą zostać prawnymi(...)"3. Wynika z niego jasno, iż dzieci urodzone z rodziców będących w stanie wolnym mają szanse na zostanie pełnoprawnymi członkami rodziny. Jednak, aby uzyskać status dziecka małżeńskiego musiało dojść do spełnienia przesłanek takich jak zawarcie związku małżeńskiego przez rodziców naturalnych, lub ojciec dobrowolnie uznałby dziecko, bądź poprzez uznanie sądowe $^{4}$. Niezwykle trudne było dochodzenie na drodze sądowej, ponieważ formalnie prawo zabraniało dochodzenia przez dziecko ojcostwa $a^{5}$. W tym wypadku można by się zastanowić, czy kodyfikator drwił z dzieci, które znalazły się w takiej sytuacji prawnej. W początkowej części artykułu czytamy, że możliwe jest, aby dzieci przysposobić. Jednak zaraz potem, w kolejnym wersie tego samego zapisu, wyznacza trudności niemalże nie do pokonania.

Kolejną kategorią dzieci pozamałżeńskich, którą wymienia art. $331 \mathrm{KCN}$

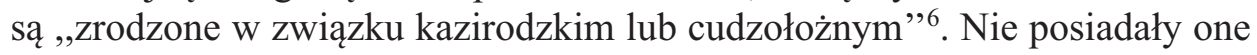
żadnych praw, nawet tych nielicznych, które przysługiwały dzieciom naturalnym zrodzonym ze związków pozamałżeńskich. Na mocy art. $335 \mathrm{KCN}$ jasno stwierdzono, iż ,uznanie takie nie może służyć dzieciom zrodzonym w kazirodztwie lub cudzołóstwie"7. Po przestudiowaniu zaledwie paru artykułów KCN widać wyraźnie podział na dwie grupy dzieci. Pierwszą stanowi kategoria dzieci wyróżnionych, których rodzice pochodzą z nieformalnego związku, ale nie łączą ich żadne więzy krwi. Te dzieci są lepsze, mogą w przyszłości uzyskać status dziecka naturalnego o ile ich rodzice spełnią przesłanki określone w cytowanych przeze mnie artykułach. Warto sobie postawić pytanie, czy ci młodzi ludzie w świetle kodyfikacji Napoleona będą posiadali takie same prawa jak ich rówieśnicy pochodzący ze sformalizowanych związków małżeńskich? Odpowiedź znajdujemy szybko w artykule $338 \mathrm{KCN}$, w którym ustawodawca zaznaczył, że „dziecię naturalne, uzna-

\footnotetext{
${ }^{3}$ Kodex Napoleona z przypisami: ksiag trzy w jednym tomie, Warszawa 1810, s. 88.

${ }^{4}$ J. Bardach, Historia państwa i prawa Polski, Warszawa 1999, s. 267.

${ }^{5}$ Ibidem.

${ }^{6}$ Kodex Napoleona z przypisami..., s. 88.

${ }^{7}$ Ibidem, s. 89.
} 
ne, nie może się odwoływać do praw dziecięcia prawnego (...)"8. Mamy tu od razu jednoznacznie powiedziane, że dziecko, nawet uznane, nie może rościć sobie w przyszłości szeregu praw, które posiadło dziecko naturalne. Ustawodawca jednak w dalszej części artykułu daje możliwość owym młodym ludziom uczestniczenia w prawie do spadku po rodzicach. Jednakże ustawodawca zaznaczył, że regulacje zostały dokładnie określone w Tytule o Spadkach.

III. Omawiając zagadnienie praw dzieci zrodzonych ze związków pozamałżeńskich, szczególną uwagę należy zwrócić na Księgę III KCP, gdzie uregulowany został dział o spadkach. Już na wstępie na pierwszy plan wysuwa się przytaczany przeze mnie podział na dzieci nieślubne - dzieci lepsze i gorsze.

W myśl treści art. $350 \mathrm{KCN}$,dzieci naturalne nie są dziedzicami: prawo wtenczas tylko dozwala im praw gdy są prawnie uznane"9. Zatem widać, iż aby posiadać możliwość dziedziczenia, dziecko musi zostać uznane przez rodziców. Co w takim razie z dziećmi pochodzących ze związków kazirodzkich lub cudzołożnych? Otóż małoletni mógł ubiegać się na mocy zapisu wynikającego z art. $762 \mathrm{KCP}$,prawa przyznania mu tylko alimentów"10. Tracił jednak wszelkie pretensje do spuścizny po rodzicach, gdy ci za życia doprowadzili do tego, aby posiadł umiejętności (rzemiosła), które pozwalały mu na dalszy byt. Jasno wynika to z art. $764 \mathrm{KCP}$,skoro ojciec lub matka dziecięcia z cudzołóstwa lub kazirodztwa, nauczyli go sztuki mechanicznej, albo jedno z nich za życia swego wyznaczyło mu alimenty, dziecię nie może się niczego dopominać w spadkach" ${ }^{11}$. Zatem widać tu wyraźne możliwości prawne, jakie posiadali rodzice względem swoich dzieci. Mogą oni za swego życia przekazać dziecku możliwości nauki pracy, która pozwoli mu na dalszą egzystencję nawet po utracie najbliższych. Ustawodawca jednak w dalszej części tegoż artykułu obligatoryjnie określił, że dziecko takie nie może dochodzić prawa dziedziczenia.

Udział dzieci w prawie do spadku dotyczył wyłącznie dóbr po zmarłych rodzicach. Nie sięgał już do majątku krewnych ojca lub matki. Na mocy art. 350 $\mathrm{KCN}$,„przysposobiony nie nabywa żadnego prawa dziedziczenia co do dóbr po krewnych przysposobiciela, ale należy do spadku po przysposobicielu"12. Ponadto był ograniczony w porównaniu $\mathrm{z}$ udziałem dzieci pochodzących ze związku małżeńskiego. Dokładny podział został unormowany w art. 757 KCN. Określał on precyzyjnie, które dzieci a także w jakim wymiarze mają prawo do spadku po rodzicach. Otóż, w udziale w dziedziczeniu w zbiegu

\footnotetext{
${ }^{8}$ Ibidem, s. 90.

${ }^{9}$ Ibidem, s. 72.

${ }^{10}$ Ibidem, s. 210.

11 Ibidem.

12 Ibidem, s. 88.
} 
ze zstępnymi prawnymi, dziecku naturalnemu przysługuje 1/3 udziału dziecka prawnego (pochodzącego ze sformalizowanego związku małżeńskiego). W przypadku zbiegu ze wstępnymi i rodzeństwem - 1/2 spadku ${ }^{13}$.

Małoletni prawnie uznani z mocy art. $758 \mathrm{KCN}$,,ma prawo do całości majątku”. Jednakże ustawodawca $w$ dalszej części zapisu dopowiada w jakim jedynym przypadku dziecko te prawo posiada. Możliwość dziedziczenia całego spadku po rodzicach istnieje wtedy tylko, gdy dziecko nie posiada rodzeństwa ani innych krewnych, by można ustanowić prawo do dziedziczenia ${ }^{14}$.

IV. Fundamentem trwałości rodziny było powierzenie ojcu pełni władzy rodzicielskiej. Prawo takiego stwierdzenia daje art. $373 \mathrm{KCN}$,sam tylko ojciec taką władzę w czasie trwania małżeństwa sprawuje"15. Ustawodawca w kolejnym artykule rozszerza katalog uprawnień, jakimi dysponuje głowa rodziny. Zgodnie z zapisem art. $389 \mathrm{KCN}$,w czasie trwania związku małżeńskiego ojciec jest rządcą osobistych dóbr małoletnich dzieci swoich (...)"16. Widać tu wyraźnie rolę, jaką odgrywał ojciec w rodzinie. To on sprawował całkowitą władzę nad osobami, a także majątkiem. Młodzi ludzie zgodnie $\mathrm{z}$ art. $371 \mathrm{KCN}$ nie mają prawa sprzeciwić się rodzicom, ściślej rzecz ujmując - ojcu ${ }^{17}$. W każdym wieku zobowiązani są szanować decyzję ojca i matki. Dziecko nie może opuścić domu ojcowskiego bez jego wyraźnego pozwolenia, co zostało unormowane przez ustawodawcę w pierwszej części art. $374 \mathrm{KCN}^{18}$. Jednak w następnej części omawianego artykułu ustawodawca dał możliwość wyprowadzenia się od rodziców, bez żądania pozwolenia. Zgodnie z zapisami Kodeksu Cywilnego Napoleona taka sytuacja może mieć miejsce tylko w przypadku ,przyjęcia wojskowej służby dobrowolnie, po skończonym 18. roku wieku swego" art. $374 \mathrm{KCN}^{19}$.

Kodeks Cywilny Napoleona ponadto przyznawał ojcu szczególne instrumenty wykonywania władzy rodzicielskiej, zwane ,środkami poprawy”, które pozwalały na stosowanie przymusu wobec dzieci: ,Jeżeli dziecię 16 lat nie zaczęło, może go ojciec trzymać w zamknięciu na czas nie dłuższy niż jeden miesiąc (...)", art. $376 \mathrm{KCN}^{20}$. Ojciec mający bardzo ważne powody do niezadowolenia z postępowania dziecka mógł zażądać jego zamknięcia w odosobnionym miejscu na okres najwyżej jednego miesiąca. Nie znalazłam artykułu, w którym stosując w stosunku do dziecka karę takiego rodzaju ro-

\footnotetext{
13 Ibidem, s. 208.

${ }^{14}$ Ibidem.

${ }^{15}$ Ibidem, s. 99.

${ }^{16}$ Ibidem, s. 104.

${ }^{17}$ Ibidem, s. 100.

${ }^{18}$ Ibidem, s. 98.

${ }^{19}$ K. Sójka-Zielińska, Kodeks...., s. 93.

${ }^{20}$ Kodex Napoleona z przypisami..., s. 100.
} 
dzic, musiałby umotywować przyczynę nałożenia przez siebie takiego rodzaju kary. Warto się zastanowić, czy owe środki poprawy nie były nadużywane przez głowę rodziny.

Kodyfikacja Napoleona ustanowiła również sytuację dzieci, które „od lat 16 zaczętych aż do pełnoletności (...) ojciec może żądać zamknięcia dziecięcia swego na sześć miesięcy najdłużej”, art. $377 \mathrm{KCN}^{21}$. Widać tu tok myślenia, że im dziecko starsze, tym surowsze i dłuższe winny być kary. Trudno odnieść się do tych środków poprawczych, gdyż ustawodawca nie określił, jakie czyny podlegają karom. Inaczej powinno się karać dziecko, które dopuściło się rozboju a inaczej takie, które ukradło ołówek kolegi, bo miał ładniejszy.

Kodyfikacja Napoleona drastycznie ograniczała pozycję dzieci w rodzinie. Mamy szereg artykułów, które mówią, co dzieci muszą, a także czego im nie wolno robić. Jedyną osobą, wokół której toczyło się życie rodzinne, był ojciec. To on stał na straży praw panujących w „,czterech ścianach”. Do jego obowiązków należało strzeżenie majątku dzieci, stosowanie środków poprawczych. Od niego zależało, czy dziecko uzyska status dziecka naturalnego, uznanego. Rola kobiety była wyraźnie uszczuplona w świetle KCN. Jedynie w przypadku rozwodu, śmierci naturalnej lub cywilnej, matka miała szansę sprawować pełnoprawną opiekę nad małoletnimi dziećmi, co wynika z art. $390 \mathrm{KCN}^{22}$.

Problem dzieci nieślubnych został dostrzeżony w początkach wieku XX. W pochodzącej z 13/26 V 1913 r. ustawie o zastosowaniu do Królestwa Polskiego zasad zdania Rady Państwa z 3 czerwca 1902 r. o polepszeniu losu dzieci nieślubnych dostrzegamy duży krok do przodu w bardziej humanitarnym podejściu do dzieci zrodzonych spoza związku małżeńskiego. Już w art. 2 omawianej ustawy dostrzeżona została szansa na pozyskanie przez ,„dzieci nieślubne, zrodzone $\mathrm{z}$ cudzołóstwa lub z takiego związku kazirodczego" statusu dziecka ślubnego ${ }^{23}$. Jednak ich rodzice muszą spełnić przesłanki, które zostały wymienione w dalszej części art. 2 ustawy. Mianowicie musi dojść do zawarcia związku małżeńskiego, na którego scementowanie winien wydać zgodę Najwyższy $(\mathrm{Sąd})^{24}$. Ponadto na mocy art. 3 cytowanej ustawy ,uznanie dziecka nieślubnego przez jego ojca dopuszczalne jest również w toku wszczętej przeciwko niemu sprawy o alimenty (...)". Małoletni na mocy tego zapisu ma prawną możliwość wystąpienia przeciwko ojcu na drogę sądową ${ }^{25}$. W kodyfikacji Napoleona była to sytuacja niemożliwa. Ponieważ prawo zabraniało dochodzenia przez dziecko ojcostwa.

${ }^{21}$ Ibidem, s. 101.

${ }^{22}$ Ibidem, s. 105.

${ }^{23}$ Ustawa z dnia 13/26 maja 1913 r. o zastosowaniu do Królestwa Polskiego zasad zdania Rady Państwa z dnia 3 czerwca 1902 r. o polepszeniu losu dzieci nieślubnych, s. 485.

${ }^{24}$ Ibidem.

${ }^{25}$ Ibidem. 
W ustawie o polepszeniu losu dzieci nieślubnych występują wyraźne dyrektywy do fakultatywnego postępowania ojca. Już nie tylko dziecko względem ojca ma powinności, ale również ojciec wobec swoich dzieci. Zgodnie $\mathrm{z}$ art. 7 cytowanej ustawy „obowiązek ojca dostarczania dziecku nieślubnemu środków utrzymania ustaje i przed dojściem dziecka do pełnoletniości (...)" ${ }^{26}$.

Uregulowane zostały również kwestie finansów i kosztów utrzymania dziecka. Otóż w myśl art. 9 ustawy „ojciec dziecka nieślubnego obowiązany jest ponieść wydatki konieczne (...)". Art. 10 ustawy mówi o możliwości „,powiększenia lub zmniejszania” kosztów utrzymania w zależności od potrzeb dziecka, a także sytuacji materialnej matki. Zgodnie z art. 11 omawianej ustawy uregulowana została również kwestia ,wypłaty na utrzymanie dziecka nieślubnego". W dalszej części art. 11 określony został konkretny sposób, w jaki ma się odbyć procedura przekazywania środków. Ustawodawca zaznaczył, iż „ma się to odbyć za zgodą stron, rozważoną przez radą opiekuńczą, sprawującą obowiązki rady familijnej, i zatwierdzone przez sąd”. Natomiast przekazane majątki powinny być ,wydatkowane zgodnie z ich przeznaczeniem"27.

Widać wyraźnie poprawę sytuacji prawnej życia dzieci nieślubnych. Mają one nie tylko obowiązki, ale także własne prawa. Prawa te mogą rościć nawet wobec ojca. Niestety w ustawie o dzieciach nieślubnych nie poruszono kwestii dziedziczenia. Być może źródło milczy, ponieważ było oczywiste, że na dziecko zyskujące status dziecka ślubnego przechodzą wszystkie prawa, jakie posiada jego rodzeństwo (pochodzące $\mathrm{z}$ formalnego związku małżeńskiego). Pomimo to uważam, że ustawa miała ogromny wkład dla polepszenia życia, jak również statusu prawnego dzieci pochodzących z nieformalnych związków.

V. Warto także wspomnieć, jak kształtowało się prawo małżeńskie w świetle zapisów wynikających z Kodeksu Napoleona. Instytucja ta bowiem ściśle wiązała się i nadal ma związek z sytuacją prawną dzieci. W dziedzinie prawa małżeńskiego kodyfikacja napoleońska utrzymywała przeprowadzoną $\mathrm{w}$ dobie rewolucji reformę, wprowadzając pełną laicyzację małżeństwa. Proces sekularyzacji prawa małżeńskiego sięgał XV w., z pełnym ugruntowaniem się od XVI w. zasady, że przepisy prawa kanonicznego w sprawach małżeństwa nabierały mocy prawnej tylko poprzez uznanie w ordonansach królewskich $^{28}$.

Czasy rewolucji przyniosły ze sobą całkowitą sekularyzację prawa małżeńskiego. Konstytucja z 1791 r. głosiła, że pod względem prawnym małżeń-

${ }^{26}$ Ibidem, s. 486.

${ }^{27}$ Ustawa z dnia 13/26 maja 1913r. o zastosowaniu do Królestwa Polskiego zasad zdania Rady Państwa z dnia 3 czerwca 1902 r..., s. 486.

${ }^{28}$ H. Konic, Dzieje prawa matżeńskiego w Królestwie Polskim, Kraków 1903, s. 23. 
stwo traktowane jest jako umowa ściśle cywilna ${ }^{29}$. Natomiast Dekret z 1792 r. przewidywał świecką formę zawarcia małżeństwa przed urzędnikiem municypalnym ${ }^{30}$.

W materii prawa małżeńskiego Kodeks Napoleona oparł się na postanowieniach prawa rewolucyjnego. Usankcjonował cywilny charakter małżeństwa, polegający na obowiązkowym ślubie cywilnym przed urzędnikiem stanu cywilnego ${ }^{31}$.

Zasady prawa napoleońskiego stały się z jednej strony wzorem dla wieku późniejszych ustawodawstw cywilnych, z drugiej zaś strony - były powodem silnej opozycji sfer duchownych przeciw całej kodyfikacji ${ }^{32}$.

Przyjęty w kodeksie Napoleona wiek uprawnionego do zawarcia małżeństwa nie pokrywał się z przyjętą w nim granicą pełnoletniości (21 lat) i wynosił dla mężczyzn 18 lat, dla kobiet zaś 15 lat (art. $144 \mathrm{KCN})^{33}$. Tak niska granica wieku tłumaczona była nie tylko wpływem prawa kanonicznego, ale i okolicznością, że względy majątkowe często decydują o dopuszczaniu przez rodziców do małżeństw dzieci jeszcze niepełnoletnich. Kodeks Napoleona wymagał bezwzględnego zezwolenia rodziców lub dziadków na zawarcie małżeństwa przez kobiety do 21 lat, a mężczyzn do 25 lat (art. $148 \mathrm{KCN})^{34}$. Co więcej, ustawodawca w dalszej części artykułu zaznaczył, iż pomimo osiągnięcia tego wieku, należy przed zawarciem małżeństwa zwrócić się do rodziców o radę $\mathrm{w}$ formalnym akcie uszanowania.

W dziedzinie stosunków prawnych między małżonkami KCN sankcjonował pełną dominację mężczyzny w związku małżeńskim. Mąż był głową związku i posiadał nad żoną władzę mężowską, której skutkiem była niezdolność żony do działań prawnych bez zezwolenia męża. Żona była zobowiązana w świetle art. $213 \mathrm{KCN}$ do posłuszeństwa, a także musiała „mieszkać z mężem i iść z nim wszędzie, gdzie mu się podobało"35. Kodeks zaliczał mężatkę do kategorii niezdolnych do zawierania umów (art. $1124 \mathrm{KCN}$ ) ${ }^{36}$. Zgodnie z art. $217 \mathrm{KCN}$ żona nie mogła ,czynić darowizn, zbywać, obciążać, hipotekować, nabywać pod tytułem darmym lub obciążliwym"37. Mogła jedynie samodzielnie sporządzić testament (art. $226 \mathrm{KCN}$ ). Mężatka nie mogła bez zgody męża stawić się w sądzie (art. $215 \mathrm{KCN}$ ). Cudzołóstwo żony było traktowane jako wystarczający powód dla męża do rozwodu w świetle

${ }^{29}$ Ibidem, s. 33-34

${ }^{30}$ Ibidem, s. 35.

${ }^{31}$ S. Zawadzki, Prawo cywilne obowiąujące w Królestwie Polskim, t. I, Warszawa 1860-1863 , s. 76-77.

${ }^{32}$ H. Konic, op. cit., s. 42.

${ }^{33}$ Kodex Napoleona z przypisami..., s. 56.

${ }^{34}$ Ibidem, s. 57.

${ }^{35}$ Ibidem, s. 76.

${ }^{36}$ Ibidem, s. 215.

${ }^{37}$ Ibidem, s. 81. 
art. $229 \mathrm{KCN}$. Natomiast żona mogła żądać rozwodu z przyczyn cudzołóstwa męża dopiero wówczas, gdy ,ten trzymał nałożnicę w domu wspólnym” (art. $230 \mathrm{KCN})^{38}$.

VI. Prawo cywilne regulowane przez XIX-wieczne kodeksy na pierwszy plan wysunęło pozycję ojca i męża. To jemu mieli się podporządkować wszyscy członkowie rodziny. Doskonale to widać na przykładzie artykułów zaczerpniętych z Kodeksu Cywilnego Napoleona - do ojca należała niemal cała władza. Zarządzał on majątkiem, decydował, czy dziecko zostanie ukarane czy też nie, stanowił także o środkach karnych. Jednak czy jeden człowiek jest w stanie dzielić i zarządzać sprawiedliwie? Trudno o odpowiedź na to pytanie, każdy bowiem ocenia swoje postępowanie w subiektywnych kategoriach moralności, sumienia, etyki. To, co jednemu człowiekowi wydaje się być surowym karceniem, inny nazwie przywołaniem do porządku. Zatem, aby nie dochodziło do nadużyć, należy w sposób dostateczny skodyfikować obowiązujące prawo. Tak też czynili ówcześni myśliciele i ustawodawcy, ale czy próba skodyfikowania systemu państwowego znajdującego się pod panowaniem trzech państw zaborczych jest realna? Trudno jest ujednolicić prawo w państwie, gdy każda z ustaw inaczej reguluje poszczególne kwestie ustroju społecznego.

Dzieci nieślubne w świetle KCN wiodły trudny żywot. Nie posiadały niemalże żadnych praw. Nie mogły dowieść ojcostwa, bowiem nie realne było wejście na drogę sądową. Jedyne co zagwarantowała im kodyfikacja Napoleona, to obowiązek całkowitej podległości oraz posłuszeństwa wobec ojca. Można by się z tym nie zgodzić, twierdząc, że przecież miały prawo do spadku. Jednak przytaczając art. $756 \mathrm{KCN}$, w którym ustawodawca zaznaczył, iż „dzieci naturalne nie są dziedzicami (...)"39. Oczywiście w dalszej części artykułu zapisana została możliwość otrzymania praw do majątku rodziców, ale tylko wtedy, gdy dziecko będzie prawnie uznane. Ponadto dzieci, nawet te które uzyskały status dziecka prawnego, nie posiadały możliwości nabywania spadku po krewnych rodziców (art. $350 \mathrm{KCN})^{40}$. Także tacy młodzi ludzie niby istnieli, a z drugiej strony nie mieli żadnej możliwości manewrów w poszukiwaniu sprzymierzeńców wśród prawa, gdyż ustawodawca w sposób jednoznaczny określił ich miejsce w hierarchii społecznej.

Sytuacja dzieci została zauważona dopiero w ustawie o dzieciach nieślubnych. Nie dzielono już w niej młodych ludzi na lepszych czy gorszych. Zarówno dzieci pozamałżeńskie jak i ze związków kazirodzkich lub cudzołożnych miały te same prawa. Dopuszczona została w ustawie możliwość

\footnotetext{
38 Ibidem.

${ }^{39}$ Ibidem, s. 208.

${ }^{40}$ Ibidem, s. 88 .
} 
wstąpienia dziecka na drogę sądową przeciwko ojcu. Taka sytuacja była niemożliwa w świetle kodyfikacji Napoleona.

Prawodawca w ustawie o dzieciach nieślubnych określa powinności ojca względem małoletnich. Obowiązkiem jego jest dostarczanie dziecku środków do egzystencji, jeżeli samo nie jest w stanie zaspokoić swoich potrzeb.

$\mathrm{KCN}$ w sposób surowy podchodzi do tematu dzieci nieślubnych. Ojciec zgodnie $\mathrm{z}$ nim, jest w stanie zrobić wszystko, nikt nie może się mu sprzeciwić, ponieważ status prawny matki mało odbiega od pozycji prawnej dziecka. Na zasadzie porównania zestawiłam dwie kodyfikacje. Jedna z początków XIX w., druga z przełomu wieków XIX i XX. Wyraźnie zarysowała się droga metamorfozy prawnej ojca. $\mathrm{Z}$ pana domu przekształca się on w członka rodziny, który ma również obowiązki. Cieszy mnie fakt, że prawo dotyczące dzieci zostało dostrzeżone. Bowiem nie od dziś jest wiadomo, że często dzieci ponoszą odpowiedzialność za błędy swoich ojców i matek. A w takiej właśnie sytuacji znaleźli się małoletni, którzy zupełnie nie mieli wpływu na to, czy się urodzą z pełnoprawnego związku małżeńskiego, czy też ich rodziców będzie łączyła więź krwi, która wyklucza założenie przez nich rodziny. 
